\title{
An Exploration of Strategies of Human Resource Supervisor in Facilitating the Achievement of Organizational Goals: Implications for HR and Organizational Development
}

\author{
Rukhsar Ahmed*, Jawed Aziz Masudi, Khalid Hafeez and Urooj Ahmed \\ Shaheed Zulfiqar Ali Bhutto University of Law, Karachi. Pakistan \\ rukhsarahmed2000@yahoo.com; jawed.masudi@gmail.com; Khalid.hafeez@hotmail.com; $\underline{\text { urooj22@ymail.com }}$ \\ Correspondence: rukhsarahmed2000@yahoo.com
}

Received: 24 $4^{\text {th }}$ August 2020; Accepted: 19 ${ }^{\text {th }}$ October 2020; Published: $1^{\text {st }}$ November 2020

Abstract: The study of the role of Human Resource supervisor in achieving organization goals is very much useful and functional managers as well as for top-level management and entry-level employees in order to get success and attainment of their objectives. This study is helpful for almost every organization since every organization has an HR department, and this research covers how to attain organizational objectives and goals to fulfill the mission and vision of the company by applying innovative tactics and procedures to get maximum results. Accordingly, the results shed light on how to train the employees to complete the tasks appropriately and precisely. The relationship between human resource supervisor and organization goals has always been of great concernment for researchers and organizational scientists. This research takes the entire plan moreover by relating the set-up of different sectors in Karachi, Pakistan.

Keywords: HR; Management; Organization Development; Human Resources Manager; Organization Goals

\section{Introduction}

For any company, the HR department plays a vital role in order to attain different organizational goals. For example, profit generation, task completion, and high employee performance achieve targets on time.HR is the foundation of the organization as they bring the workforce into the organization. HR work generally starts with hiring the right candidates for the right job at the right time. If this process is done effectively, everything then will work best for the company. HRM has remained strategically important for businesses (Channa et al., 2020). The main objective of HR is to increase their productivity. In the 1980's human resource department appeared as a distinctly explained idea of staff management.

During early 1980s, human resource supervisors were involved more in doing paperwork and authorized issues. However, today, the human resources supervisors are more engaged in working with their employees, sharing information and experiences, and working with their top management and executive level (Sanders, Shipton \& Gomes, 2014). There is more collaboration among HR top executives 
and its employees, which shows a sign of success. People started to work in teams, cooperate, achieve targets on time. According to some studies, HR executives will have a broad scope in the future, and human resource supervisors should adopt some practices in the future consistently, such as recruitment and selection, training \& development, and performance and compensation to meet its objectives. (Tremblay et al., 2010). HR should also focus on continuous learning so that they can meet challenges in a dynamic business world. HR supervisors and executives encourage their employees to learn more and apply new things to compete with others. Therefore, to learn how the HR department helps the organization in meeting its objectives, this research will help in analyzing the relationship between Human Resource Supervisor and Organization Goals.

The essential thing in HR is its people whom they hire and who are working in their company. People think that HR is just about managing payroll, making compensation plans, doing performance appraisals. Nevertheless, NO! HR has different branches, and today HR is a broad department that deals with recruitment and selection, performance and compensation, training and development, and so on (Mihardjo et al., 2020). The recruitment and selection process of the organization costs much money, say $70 \%$ to $80 \%$ of the total expenses of the company. Thus, this process needs to be done very carefully because the company has some fixed budget, and it has to bear other expenses also. Research showed that $59 \%$ of the companies keep checking their compensation and benefits plans regularly, while $52 \%$ of the companies use different designing tools for staffing. According to some studies, only those companies will prosper whose HR supervisors/managers are well aware of the new and different surroundings and who are ready to face tough competition and gets successful only these organizations can survive in the industry (Huynh et al., 2014). Human capital is one of the rarest and precious assets of any organization as they are the asset who can bring business to the company, and the company can get maximum profits. In Pakistan, there is low utilization of human capital because employees are mistreated by managers (Iqbal \& Rasheed, 2019), which creates a lack of interest of employees towards their work.

\section{Literature Review}

According to Nadiv et al. (2017), the HR manager/supervisor is the one who plans, organizes, directs, and controls operations accordingly in order to achieve organizational goals. HR managers play a major role in any organization for the successful utilization of other resources. HR is also responsible for managing its people so that they can work up to the expectations of the company. HR supervisor/ manager provides guidance and training to its employees to know what to achieve and how to achieve. According to Ganesh (2018), HR managers have different roles in the company, but their essential task is to draw up plans that are totally based on the recruitment and selection process and also to keep a check on their projects in order to increase their productivity.

There is an association between HR supervisors who helps a company's management in attaining company goals through innovative strategies tends to produce more outputs and increase employee performance for better achievement of organizational goals. According to Sree Rama Rao(2012), in some organizations, HR supervisors encourages teamwork, which creates the right environment for the employees to interact with each other and share their knowledge, and this helps in completing their task effectively.HR supervisors also work both on long as well as short term goals to make a correlation between company goals and personnel goals.

As per Pomoni (2009), to achieve business goals and complete tasks, HR supervisors instruct and encourage the employees by sharing the policies and procedures with them and discussing company issues. According to Antila (2006), it is the crucial role of HR supervisors/managers to create a sense of belongingness and one team among its people. According to Smita (2011), by sharing accurate and relevant information with the employees, HR supervisors can benefit the organization because the employees will know that where the organization is standing now and where they are willing to go this will help the 
company in achieving their goals efficiently. As per Dessler (2011), Successful HR supervisors/managers know best how to track employee's performance, how to provide them feedback, how to motivate them, how to develop and polish their skills, and also whom to assign work and how to assign. HR supervisor/manager should make sure that the person to whom he is assigning work is capable of completing the task or not. HR provides clear and adequate information to its employees so that the employees have a clear vision of how to meet the targets and objectives of the organization. According to Krishnaveni and Monica (2018), HR supervisors/ managers help the company to generate profits when their recruitment and selection process is effectively done and at the right time in hiring the right person. This also helps the company save training costs, time, and other expenses like hiring other employees if the current employee is not giving to the company's expectations.

According to Welch and Welch (2012), the HR supervisor/manager is more proactive when it comes to "change" and "innovation". They change accordingly in the dynamic business world just to face challenges and to be successful. They (HR professionals) hire people with different and new skills. Stahl (2020) explains that HR supervisors are the ones who communicate new ideas and techniques for recruiting, retaining, and performing the employees in an organization. Moreover, if they hire capable and skilled employees, they will generate profits efficiently and effectively. According to Renwick (2003), HR supervisors motivate their employees to get the task done correctly and on time. A good HR supervisor knows how and when to motivate his employees and when the task is completed, he also knows how to reward his employees. Kloeber (2013) says that the HR supervisor is responsible for getting/ hiring the right people at the right time. He should know which position to fill with which employee. Hiring the right people in the organization means the profit generation will be more and high costs will be eliminated.

According to Lengnick-Hall and Lengnick-Hall (2003), relationships with the employees and subordinates play a vital role in gaining a competitive advantage. Building relationships with employees and having a great flow of information within the organization can lead the organization towards success. If an HR supervisor works strategically, he can quickly increase the profitability and productivity of the company. Managers must ensure that their employees are highly motivated and happy with the work assigned to them. When they have a feeling that they are treated fairly, they will take more interest in their work, and in this, the performance of the company will increase (Bryson \& White, 2019).

The main and the most crucial task that is performed by HR professionals/ supervisors/managers is the process of recruitment and selection process. If their recruitment or hiring process is effective, it is a sign of success for the organization. It is the most challenging job to get the right candidate at the right time for the right job. Many big companies also fail in their recruitment and selection process because they do not know when to recruit and how to recruit for which position. An HR supervisor/manager/ professional should know how to utilize their organization resources. They must ensure that they are utilizing their resources at the right time in the right way. A strategic human resource supervisor/ manager must have mastery skills and know-how to treat and assigned work to his employees so that he can easily manage his employees, and in this way, the employees will also serve in a better way to the customers. It is also important for the HR supervisor/manager to keep a check on his employees and track their performance daily so that if they lack in anywhere so they can be sent for training where his skills can be polished. In well-reputed organizations, employees and managers / senior executives are flexible. They are ready to face challenges anytime. Because the business world keeps on changing, so with time to time, the organization should also adopt change and keep themselves updated. Furthermore, for that purpose, training and development of the employees plays a significant role so that employees learn continuously that:

- What is going on nowadays?

- How to face the challenge?

- What strategies to use for the betterment of the company? 
- How to generate profits and minimize costs through new techniques?

- How to encourage employees to complete tasks before time?

According to Arifin et al. (2020), getting higher profits and high performance, HR needs to focus on their hiring process because they are the one who deals with this. They should be cautious while hiring new employees because they pay for the recruitment and selection process. If this process is not done correctly, the company will face a big failure after some time. HR supervisor/ manager should also concentrate when they fire someone from the organization; he must ensure that whether the employee which he is firing is not capable, or not take an interest, or does not meet the requirements of the organization. One thing that an HR supervisor/manager should keep in mind is to give feedback to their employees. Because if they (supervisor) do not respond on the performance of the employees, then the employees will be unaware of their performance, and there will be fewer chances of improvement for the employees. When employee performance is appraised, they will know that the supervisor/manager is keeping a check on them. Hence, giving feedback on regular basis also plays a major role to improve performance (Delery \& Roumpi, 2017).

HR supervisors/managers should make up a compensation plan, which is fair. The employee who is more deserving and the employee who is less deserving should not get the same compensation plan. The compensation plan should be made according to the performance and position of the employee. If one employee is working more and giving more time to his job and on the other hand of the other employee is just doing his job just to get money and not taking an interest in his work and not dedicated to his work, then they should not be paid equally as this will create dissatisfaction among the employees.

According to some studies, an HR supervisor/manager should create an environment where the employees get respect, should be treated well. HR professionals should develop a good relationship with their employees so that the employees work more efficiently. The employees should be provided with current information. An HR supervisor/manager should be unbiased; he must ensure that not to give any favor to anyone and treat everyone equally; otherwise, the employees will realize that they are not treated as good as others are treated, and this will create demotivation and differences among the employees.

In some large and reputed organizations, the employees get on the job training (OJT), where they get training from the workplace. To be successful in the industry, it is necessary to focus more on flexibility and innovation because things keep changing. A strategic human resource supervisor/manager, it is equally important to keep a check on the external environment of the company to explore:

- What are others serving to their customers?

- How are they serving?

- What technology are they using to meet the change?

- What new things are they innovating?

- How to compete with the competitors?

In some companies, HR managers also help their company to get a competitive advantage over rivals. This strategy is done by hiring the right candidates for the job, making a type of staff which is dedicated to their work, they are more focused to the future of the organization, those employees not only plan for short term goals but they also plan on how to achieve the long term goals of the company (Delery \& Roumpi, 2017). Do successful organizations have effective HR professionals who are much aware of their organization's needs, such as they know what employees do they need? How many employees do they need? From where should they start their recruitment process? When should they end up their recruitment process? Do they have a rich workforce in the organization? How many employees do they have who are more competent and able to achieve targets and are less competent? When the HR supervisors/professionals have much knowledge about all the questions discussed above, then he (HR supervisor/professional) is the one who can bring a good chance in the organization and have a good 
mindset and idea of how to run the organization successfully. This is the indication of a brilliant HR supervisor/professional (Pfeffer \& Veiga, 1999).

\section{Data Analysis and Results}

\subsection{Findings and Interpretation of the results}

According to the data file, Regression and ANOVA technique has been applied. The reason for applying this technique is to see the relationship between two variables, i.e., HR Supervisor with Profit Generation and Task Completion, where HR Supervisor is an Independent variable and profit generation and Task Completion are Dependent variables.

Table 1. Model Summary

\begin{tabular}{|l|l|l|l|l|}
\hline Model & $\mathbf{R}$ & R Square & Adjusted R Square & Std. Error of the Estimate \\
\hline $\mathbf{1}$ & $.521^{a}$ & .272 & .269 & .65247 \\
\hline
\end{tabular}

a. Predictors: (Constant), HR_Supervisor

Table 2. ANOVA ${ }^{\mathrm{b}}$

\begin{tabular}{|l|l|l|l|l|l|l|}
\hline \multicolumn{2}{|l|}{ Model } & Sum of Squares & df & Mean Square & F & Sig. \\
\hline \multirow{4}{*}{1} & Regression & 44.921 & 1 & 44.921 & 105.519 & $.000^{a}$ \\
\cline { 2 - 8 } & Residual & 120.477 & 283 & .426 & & \\
\cline { 2 - 7 } & Total & 165.397 & 284 & & & \\
\hline
\end{tabular}

a. Predictors: (Constant), HR_Supervisor

b. Dependent Variable: Profit Generation

Table 3. Coefficients

\begin{tabular}{|c|c|c|c|c|c|c|}
\hline \multirow{2}{*}{\multicolumn{2}{|c|}{ Model }} & \multicolumn{2}{|c|}{ Unstandardized Coefficients } & \multirow{2}{*}{\begin{tabular}{|l} 
Standardized Coefficients \\
Beta
\end{tabular}} & \multirow[b]{2}{*}{$t$} & \multirow[b]{2}{*}{ Sig. } \\
\hline & & B & Std. Error & & & \\
\hline \multirow{2}{*}{1} & (Constant) & 1.107 & .121 & & 9.180 & .000 \\
\hline & HR_Supervisor & .581 & .057 & .521 & 10.272 & .000 \\
\hline
\end{tabular}

a. Dependent Variable: Profit_Generation

In table 1 of model summary, the value of the R square of an independent variable HR Supervisor is 0.272 , which means that the Independent Variable, i.e., HR Supervisor, conjointly describes $27.2 \%$ of the variance in the Dependent Variable. As per Table 2 of ANOVA for profit generation, the F statistic value is 105.519 , the distribution is $\mathrm{F}(1,283)$, and the probability is less than 0.001 ; there is strong evidence that beta is not equal to zero. In Table 3 of coefficients, the beta is positive, i.e., .521, which means there is a positive relationship between the two variables, or we can also say that HR supervisor (IDV) is positively correlated with Profit Generation (DV). In the above table, the sig value is .000, which is less than 0.05 , so we can conclude that the test is significant, and there is a strong relationship between Human Resource Supervisor and Profit generation. Thus, H1 is accepted.

Table 4. Model Summary

\begin{tabular}{|c|c|c|c|c|}
\hline Model & $\mathbf{R}$ & R Square & Adjusted R Square & Std. Error of the Estimate \\
\hline $\mathbf{1}$ & $.419^{a}$ & .176 & .173 & .59240 \\
\hline
\end{tabular}

a. Predictors: (Constant), HR_Supervisor

In table 4 of the model summary, the R square value is .716, which means that the variable explains the $17.6 \%$ of the variances, or we can say that an HR Supervisor conjointly describes $17.6 \%$ variance of the dependent variable, i.e., Task Completion. In ANOVA Table 5, the F value is 60.252 , and the F distribution $(1,283)$, the probability is less than 0.001 . The significance value is 0.000 , which is less than 0.05 , which 
means that $\mathrm{H} 2$ is accepted because it shows a positive relationship between Human Resource Supervisor and Task completion.

Table 5. ANOVA ${ }^{b}$

\begin{tabular}{|l|l|l|l|l|l|l|}
\hline \multicolumn{2}{l|}{ Model } & Sum of Squares & df & Mean Square & F & Sig. \\
\hline \multirow{4}{*}{1} & Regression & 21.145 & 1 & 21.145 & 60.252 & $.000^{a}$ \\
\cline { 2 - 8 } & Residual & 99.316 & 283 & .351 & & \\
\cline { 2 - 8 } & Total & 120.461 & 284 & & & \\
\hline
\end{tabular}

a. Predictors: (Constant), HR_Supervisor

b. Dependent Variable: Task_Completion

Table 6. Coefficients

\begin{tabular}{|c|c|c|c|c|c|c|}
\hline \multirow{2}{*}{\multicolumn{2}{|c|}{ Model }} & \multicolumn{2}{|c|}{ Unstandardized Coefficients } & \multirow{2}{*}{\begin{tabular}{|l} 
Standardized Coefficients \\
Beta
\end{tabular}} & \multirow[b]{2}{*}{$t$} & \multirow[b]{2}{*}{ Sig } \\
\hline & & B & Std. Error & & & \\
\hline \multirow{2}{*}{1} & (Constant) & 1.393 & .109 & & 12.724 & .000 \\
\hline & HR_Supervisor & .399 & .051 & .419 & 7.762 & .000 \\
\hline
\end{tabular}

a. Dependent Variable: Task_Completion

Table 7: Summary of Results

\begin{tabular}{|l|l|l|l|l|}
\hline Sr. No & Hypothesis & F Value & Sig & Empirical Conclusion \\
\hline 1 & Human Resource supervisor helps in generating profits. & 105.519 & 0.000 & Accepted \\
\hline 2 & Human Resource supervisor helps in task completion. & 60.252 & 0.000 & Accepted \\
\hline
\end{tabular}

\section{Conclusion}

It is found that there is a positive effect of the independent variable, i.e., HR supervisor, on both dependent variables, i.e., profit generation and task completion. From the present study, we can conclude a meaningful relationship between the IDV and the DVs. Hence it is proved from the test that HR supervisors do help their organizations in achieving organization goals (Profit Generation and Task Completion) in a systematic and organized way. In many companies, HR supervisors play a key role because they are the one who set priorities and set standards and share the goals with his employees so the employees are well prepared to achieve those goals with innovative techniques and procedures.

\section{References}

Antila, E. M. (2006). The role of HR managers in international mergers and acquisitions: a multiple case study. The International Journal of Human Resource Management, 17(6), 999-1020.

Arifin, A. H., Raza, H., Saputra, J., \& Puteh, A. (2020). The Influence Of Recruitment And Career Development Towards Employee Performance: A Mediating Role Of Competence. Journal of Talent Development and Excellence, 12(1), 10401055.

Bryson, A., \& White, M. (2019). HRM and small-firm employee motivation: Before and after the great recession. ILR Review, 72(3), 749-773.

Channa, N. A., Shah, S. M. M., \& Ghumro, N. H. (2019). Uncovering the link between strategic human resource management and crisis management: Mediating role of organizational resilience. Annals of Contemporary Developments in Management \& HR (ACDMHR), 1(2). 15-27.

Delery, J. E., \& Roumpi, D. (2017). Strategic human resource management, human capital and competitive advantage: is the field going in circles?. Human Resource Management Journal, 27(1), 1-21.

Dessler, G. (2011). Fundamentals of human resource management. Pearson Higher Ed.

Ganesh, A. (2018). Competencies of HR Manager in Managing the Employee Welfare and Development in Construction Chemical Industry. Training \& Development Journal, 9(1), 10-17.

Huynh, L., Johns, B., Liu, S. H., Vedula, S. S., Li, T., \& Puhan, M. A. (2014). Cost-effectiveness of health research study participant recruitment strategies: a systematic review. Clinical Trials, 11(5), 576-583. 
Iqbal, S., \& Rasheed, M. (2019). Abusive supervision and workplace deviance: The moderating role of power distance. Pakistan Journal of Commerce and Social Sciences (PJCSS), 13(2), 334-357.

Kloeber (2013). The role of the manager: What's really important in different management jobs? The Academy of Management Executive, 19(4), 122-129.

Krishnaveni, R., \& Monica, R. (2018). Factors influencing employee performance: the role of human resource management practices and work engagement. International Journal of Business Performance Management, 19(4), 450475.

Lengnick-Hall, M. L., \& Lengnick-Hall, C. A. (2003). HR's role in building relationship networks. Academy of Management Perspectives, 17(4), 53-63.

Mihardjo, L. W., Jermsittiparsert, K., Ahmed, U., Chankoson, T., \& Hussain, H. I. (2020). Impact of key HR practices (human capital, training and rewards) on service recovery performance with mediating role of employee commitment of the Takaful industry of the Southeast Asian region. Education+ Training.

Nadiv, R., Raz, A., \& Kuna, S. (2017). What a difference a role makes: Occupational and organizational characteristics related to the HR strategic role among human resource managers. Employee Relations, 39(7), 1131-1147.

Pfeffer, J., \& Veiga, J. F. (1999). Putting people first for organizational success. Academy of Management Perspectives, 13(2), 37-48.

Pomoni.(2009). Human resource management and organizational performance. Industrial and Labor Relations Review, 57(2), 181-203.

Renwick, D. (2003). Line manager involvement in HRM: an inside view. Employee Relations, 25(3), $262-280$.

Sanders, K., Shipton, H., \& Gomes, J. F. (2014). Guest editors' introduction: Is the HRM process important? Past, current, and future challenges. Human Resource Management, 53(4), 489-503.

Smita, M. (2011). Motivation through the design of work. Organizational Behavior and Human Performance, 16, $250-279$.

Stahl, G. K., Brewster, C. J., Collings, D. G., \& Hajro, A. (2020). Enhancing the role of human resource management in corporate sustainability and social responsibility: A multi-stakeholder, multidimensional approach to HRM. Human Resource Management Review, 30(3), 100708.

Tremblay, M., Cloutier, J., Simard, G., Chênevert, D., \& Vandenberghe, C. (2010). The role of HRM practices, procedural justice, organizational support and trust in organizational commitment and in-role and extra-role performance. The international journal of human resource management, 21(3), 405-433.

Welch, C. L., \& Welch, D. E. (2012). What do HR managers really do?. Management International Review, 52(4), $597-617$.

(C) 2020 by the author(s). Published by Annals of Contemporary Developments in Management \& HR (ACDMHR), under the terms and conditions of the Creative Commons Attribution (CC BY)

license which can be accessed at http://creativecommons.org/licenses/by/4.0/. 